\title{
Prevalence of H9N2 Avian Influenza Virus in Live Bird Markets of Eastern Madhya Pradesh
}

\author{
Baleshwari Kurmi ${ }^{1,2}$, Harshad Vinayak Murugkar ${ }^{1 *}$, Manoj Kumar ${ }^{1}$, Chakradhar Tosh ${ }^{1}$, \\ Shanmugasundaram Nagarajan ${ }^{1}$, Asha Verma ${ }^{1}$, Sushil Tripathi ${ }^{1}$ and Vijendra Pal Singh ${ }^{1}$ \\ ${ }^{1}$ National Institute of High Security Animal Disease, ICAR-Bhopal, Madhya Pradesh, INDIA \\ ${ }^{2}$ Division of Veterinary Public Health and Epidemiology, CoVSc, and AHRewa, NDVSU, Jabalpur, Madhya Pradesh, India
}

*Corresponding author: HV Murugkar; E-mail: harshadmurugkar@gmail.com

Received: 18 Sept., 2020

Revised: 28 Nov., 2020

Accepted: 02 Dec., 2020

\begin{abstract}
A cross sectional study was carried out to know the status of H9N2 LPAI virus in retail poultry shops (RPSs) established in live bird markets (LBMs) of eastern Madhya Pradesh, India. A total 288 samples were collected from 4 districts of eastern Madhya Pradesh following cluster sampling method. Samples included 120 tissue samples and 168 environmental samples of live bird markets. All the samples were analysed for virus isolation by embryonated chicken egg inoculation, Hemagglutination (HA), Hemagglutination Inhibition (HI) and Reverse Transcriptase PCR (RTPCR). A prevalence of $9.2 \%$ was found in tissue samples and that of $20.8 \%$ was found in pooled environmental samples. Out of four districts in the study, samples from three districts were found positive for H9N2 AIV. A strong positive correlation (Pearson's correlation coefficient, $r=0.92$ ) was found between tissue and environmental samples. This study indicated presence and possible spread of H9N2 AIV in these LBMs. These LBMs might impose risk of acquiring infection to occupationally exposed individuals. Therefore, a proper vigilance is needed over the poultry supply chain especially the poultry retail shops along with general awareness about basic biosecurity measures for
\end{abstract} prevention and control of $\mathrm{H} 9 \mathrm{~N} 2$ infection.

\section{HIGHLIGHTS}

(0 LBM of Eastern Madhya Pradesh Showed positivity to H9N2 AIV in Birds and Environment.

(- Slaughter waste and LBM surfaces may act as a source of Infections to incoming birds.

( $)$ Silent presence of H9N2 virus may lead to emergence of new virus with zoonotic potential.

Keywords: H9N2, prevalence, Retail Poultry Shops, Prevalence, live bird markets, risk Factors

In the past few decades, the poultry industry in India is going through a drastic change in its structure and operation. India ranks $3^{\text {rd }}$ in egg production and $7^{\text {th }}$ in chicken meat production in the world. Many factors contribute to growth of poultry sector in India. Poultry meat is preferred over other meat in India because of quality of nutritional quality as well as religious believes. The poultry meat is purchased generally through spot slaughter or as live bird itself from the Live Bird Markets. Although poultry sector is growing with a rapid pace, there are certain threats which are consistently overhead. Avian Influenza (AI) in one of the factors which is continuously posing a risk to poultry industry as well as to public health. Subtypes of AIV are defined on the basis of Haemagglutinin (HA), a surface glycoprotein responsible for host cell receptor affinity and Neuraminidase (NA) which mediates virus release from host cell. 18 different Haemagglutinin (H1 to H18) subtypes and 11 different neuraminidase subtypes (N1 to N11) are known (Tong et al., 2013). On the basis of pathogenicity, AIV subtypes fall in to two categories,

How to cite this article: Kurmi, B., Murugkar, H.V., Kumar, M., Tosh, C. Nagarajan1, S., Verma, A., Tripathi, S. and Singh, V.P. (2020). Prevalence of H9N2 Avian Influenza virus in live bird markets of Eastern Madhya Pradesh. J. Anim. Res., 10(6): 1077-1083.

Source of Support: None; Conflict of Interest: None 
Highly Pathogenic Avian influenza (HPAI) that cause severe disease in poultry and result in high death rate and Low Pathogenic Avian Influenza (LPAI) that causes mild disease in poultry (Alexander, 2000). HPAI outbreaks continue to be documented worldwide and have occurred due to the H5 and H7 subtypes only (Suarez et al., 2004). H9N2 subtype is one of the LPAI virus subtypes that is prevalent all over the world. Since its first report from turkeys in the Wisconsin state of United States of America in 1966, it has been reported from many countries of world (Alexander, 2000) and has become endemic in domestic poultry in many areas of Eurasia and Africa and continuously evolving by intra-subtypic and inter-subtypic reassortment and antigenic drift, consequently increasing host range and its zoonotic potential. A few human H9N2 virus infections with mild symptoms have been reported and most of such cases had a history of contact with poultry (Suarez et al., 2004). Sero-prevalence studies for H9 antibodies in poultry and humans indicated that human which are occupationally exposed to poultry are at higher risk for H9N2 virus (Khan et al., 2015). There are evidences that indicate role of H9N2 virus in emergence of new zoonotic AIV subtypes which may act as a gene donor to other subtypes as well as gene recipients, if coinfected the host with the other subtypes viruses (Guan et al., 1999; Lam et al., 2013; Shen et al., 2016).

Live Bird Markets (LBMs) act as a hub for poultry traders and the birds. These markets are considered as a critical link between commercial farms, slaughter houses, poultry traders and final consumers. Consequently, LBMs not only act as foci for maintenance, reassortment and dissemination of AIVs among poultry, they may also facilitate zoonotic spread of the infection, particularly among the exposed human population involved in the sale, storage, slaughter, processing and transport of the poultry and poultry meat. A study indicated the presence of H9N2 in chickens of the same live bird market from where zoonotic H5N1 Hong Kong virus emerged and the virus was found to have six internal genes from H9N2 virus (Lee et al., 2010). As compared to H5 and H7 subtypes, $\mathrm{H} 9$ is relatively neglected because it is not notifiable but is found to be silently circulating in domestic poultry making it a potential candidate or contributory factor for the emergence of the next influenza pandemic virus. The status of H9N2 in the Madhya Pradesh is not known. There is much difference in poultry population, production and demand for poultry meat among various districts of Madhya Pradesh. A less emphasis over biosecurity is given in the poultry production system of the state. Poultry is generally being sold through Retail Poultry Shops (RPS) which sell both live birds as well as dressed chicken slaughtered on the spot making these places a potential exposure source for the human beings visiting these areas. Considering the scenario, a study was conducted to know the H9N2 AIV prevalence in LBMs in eastern parts of Madhya Pradesh state of India.

\section{MATERIALS METHODS}

\section{Sampling design}

As there is no published report available on prevalence of H9N2 in poultry in Madhya Pradesh, an expected prevalence of $5 \%$ was taken based on similar studies performed outside India (Thuy et al., 2016). The sample size was calculated using EpiInfo ${ }^{\mathrm{TM}}$ software, considering $5 \%$ acceptable margin of error. Samples were collected from two division namely Rewa and Shahdol, covering most of the eastern region of Madhya Pradesh. Two stage cluster sampling methodology was adopted and total four districts as first stage cluster were selected, two from each division. From each district six poultry shops form live bird markets were selected randomly as second stage cluster. A total 288 samples, 120 tissue samples and 168 environmental samples were collected. A total of 05 tissue samples (trachea, lung and Intestine) per RPS i.e. 30 samples per district were collected in Phosphate buffer saline (PBS) adding appropriate concentrations of antibiotic and antifungal agents recommended by OIE, making a total sample size of 120 tissue samples in the study (OIE 2015). A total of 168 environmental samples consisting of environmental swabs, disposal waste and water samples were collected. From each shop 3 swabs i.e. knife, slaughter, cages were collected. Swab samples were pooled together in PBS containing antibiotic and antimycotic mixture and labelled as environmental swab samples making total 24 environmental swab samples from each district. Likewise, 3 samples including slaughter waste, faecal samples from cages and feed remains in cages were pooled together in PBS and labelled as Disposal waste samples, making total 24 disposal waste samples. Water used for different slaughter operations and 
watering for birds was taken from each RPS making total 24 water sample making. All the samples were stored in thermocol boxes contains 4-6 ice packs and transported to the National Institute of High Security Animal diseases, Bhopal and processed as early as possible otherwise stored at $-80^{\circ} \mathrm{C}$ temperature till testing.

\section{Virus isolation and subtyping}

Tissue homogenates of the samples were prepared and processed for virus isolation. All pooled swab samples, water samples and disposal waste samples from a single shop were processed separately for virus isolation as recommended by OIE for isolation of avian influenza virus (OIE 2015). Sample homogenates were centrifuged at $14000 \mathrm{rpm}$ for 20 minutes and suspension was treated with antibiotic mixture for $1 \mathrm{hr}$ at $37^{\circ} \mathrm{C}$ and again centrifuged as same. Suspension of processed samples were inoculated in 9-11 day old embryonated chicken eggs (ECE) by amino-allantoic sac route and incubated at $37^{\circ} \mathrm{C}$ for five days. Inoculated embryos were checked daily for mortality. The embryo found dead within $24 \mathrm{hr}$ of incubation were suspected due to bacterial contaminants and discarded. Embryos dead after $24 \mathrm{hrs}$ and all live embryo after five days of incubation were kept at chilling for overnight and harvested to collect allantoic fluid. Allantoic fluid was tested by Hemagglutination (HA) test using $1 \%$ chicken RBC. Subtyping of the isolated virus was done by Hemagglutination Inhibition (HI) test and Reverse Transcriptase Polymerase Chain reaction (RTPCR). Viral RNA was extracted from allantoic fluid by using Qiagen RNA extraction kit. The viral RNA was tested by RTPCR using NP influenza A specific and H9 subtype specific primers (Lee et al., 2001).

\section{Statistical analysis}

Samples which were found positive in HI and RT PCR were considered as positive and accordingly prevalence was calculated. Correlation between the positivity of tissue and environmental samples for H9N2 was calculated by Pearson's correlation coefficient (r).

\section{RESULTS AND DISCUSSION}

A total of 20 out of $120(16.67 \%)$ tissue samples were found positive by Haemagglutination test. HI test for H9 antisera showed $15.83 \%(19 / 120)$ positive tissue samples. All the HI positive samples were found positive in RTPCR test for Influenza A virus and H9 specific primers with overall prevalence of $\mathrm{H} 9 \mathrm{~N} 2$ in tissue samples standing as $15.83 \%$. Highest prevalence for H9N2 standing at 26.7\% was found in Satna district followed by Rewa district with 20\% and Anuppur district with 16.7\% prevalence. None of the samples were found positive from Shahdol district (Table 1).

The poultry sector in Madhya Pradesh is relatively less organized and most of the market demand is fulfilled by small scale poultry holders and integrated system. This is the first attempt to know the extent of circulation of H9N2 virus in Madhya Pradesh. In our study, 3 out of 4 districts of eastern Madhya Pradesh were found to have H9N2 virus circulating in poultry of LBMs. Overall prevalence of virus in tissue samples was estimated to be $15.83 \%$ which is higher than with the other studies carried out in other South Asian countries where the prevalence of $\mathrm{H} 9 \mathrm{~N} 2$ in commercial poultry was $6.7 \%$ (Ali et al., 2018 ) and $8.3 \%$ from different species of birds (Kausar et al., 2018). In south Asia, H9N2 viruses are considered endemic in Bangladesh and Pakistan and are likely to be

Table 1: Prevalence of H9N2 in Tissue Samples and environmental samples

\begin{tabular}{lllllll}
\hline \multirow{2}{*}{ District } & \multicolumn{3}{c}{ Tissue samples } & \multicolumn{2}{c}{ Environmental samples } \\
\cline { 2 - 7 } & $\begin{array}{l}\text { No of } \\
\text { samples }\end{array}$ & $\begin{array}{l}\text { Samples +ve } \\
\text { (HI\&RT) }\end{array}$ & $\begin{array}{l}\text { Prevalence } \\
(\%)\end{array}$ & $\begin{array}{l}\text { No of } \\
\text { samples }\end{array}$ & $\begin{array}{l}\text { Samples +ve } \\
\text { (HI\&RT) }\end{array}$ & Prevalence \\
\hline Rewa & 30 & 6 & 20 & 18 & 5 (swab 3, disposal 2, water 0) & 27.8 \\
Satna & 30 & 8 & 26.7 & 18 & 7 (swab 3, disposal 4, water 0) & 38.9 \\
Shahdol & 30 & 0 & 0 & 18 & 0 (swab 0, disposal 0, water 0) & 0 \\
Anuppur & 30 & 5 & 16.7 & 18 & 3 (swab 1, disposal 2, water 0) & 16.7 \\
Total & 120 & 19 & $(19 / 120)$ 15.83 & 72 & 15 & $(15 / 72) 20.83$ \\
\hline
\end{tabular}






Fig. 1: Sample Collection sites and Prevalence across Eastern Madhya Pradesh

endemic in many regions of India, Afghanistan and Nepal (Peacock et al., 2019). Studies have indicated different levels of prevalence ranging from $3.7 \%$ in Vietnam and upto to $10 \%$ in Chinese provinces, Pakistan, Bangladesh and Egypt (Chu et al., 2016; Turner et al., 2017; Liu et al., 2018; Chaudhry et al., 2018).

Three out of four studied district were found to have virus in LBMs with highest in the Satna city followed by Rewa \& Anuppur, while Shahdol city was found negative to the virus. Sample prevalence was different from shop wise prevalence. In Rewa 2/6 (33.3\%) were positive while in Satna 4/6 (66.6\%) shops were positive. It indicates virus may be wide spread and need to be surveyed broadly. This difference may be due to common sources of birds for the positive shops from where the birds were procured or persistence of virus in the environment of LBMs.

Present study indicates that virus is present in LBMs of these cities and is being spread between birds. As biosecurity measure in these LBMs were not up to standards, it can be assumed that the other birds, stray animals roaming around and humans involved are at risk of exposure to virus. Prevalence of H9N2 has been reported to be much higher in LBMs as compared to the commercial poultry farm (Turner et al., 2017). This could result in humans being occupationally exposed to poultry market and are at higher risk of contracting the infection as compared to others ( $\mathrm{Li}$ et al., 2016). A sero-surveillance study from India revealed that 5\%- 6\% persons with direct exposure to poultry had H9N2 antibodies (Pawar et al., 2012). Since avian influenza virus infections do not fall in the routine diagnostic protocols for humans, the number of avian influenza viruses infecting human could be much higher than the laboratory confirmed cases (Gomaa et al., 2015). Animals like dog, cat and pigs have easy access to these areas which may provide an excellent opportunity for virus reassortment. H9N2 subtype was the only subtype which was isolated in this study. However, outbreaks of other subtypes of avian influenza virus have been reported in Madhya Pradesh. Recently, HPAI H5N1 has been reported from crows from two of the districts namely Katniand Datia (OIE, 2020) of which district Katni is adjoining the Satna district which is part of the present study and found positive for H9N2. It indicates the possibility of co-circulation of these viruses in wild birds and a potential of reassortment between these subtypes (Guan et al., 1999).

In this study, virus was isolated from swab sample and disposal waste from only those RPSs where tissue samples were found to be positive for the H9N2 virus. Disposal waste samples were the pool of slaughter waste, discarded feed and bird faeces. The swab samples were the pool of knife swab, slaughter slab swab and cages swab. A prevalence of $20.8 \%$ has been detected in pooled environmental samples with the highest prevalence in 
Satna district standing at $38.9 \%$ followed by Rewa standing at $27.8 \%$ and that for Anuppur was found to be $16.7 \%$. The environmental samples tested showed the presence of H9N2 virus only in swabs and disposal waste material with the overall $9.7 \%$ and $11.1 \%$ positivity respectively for all environmental samples. However, percent positivity for individual environmental samples was found to be $29.2 \%$ for swab samples and $33.3 \%$ for disposal waste samples. Virus could not be isolated from water samples (Table 2).

Table 2: Percent Positivity of H9N2 in different Environmental Samples

\begin{tabular}{llll}
\hline Positivity \% in Environmental Samples & & \\
\hline Environmental samples & $\begin{array}{l}\text { No of } \\
\text { sample }\end{array}$ & $\begin{array}{l}\text { Sample } \\
\text { +ve }\end{array}$ & $\begin{array}{l}\text { Positivity } \\
\text { \% }\end{array}$ \\
\hline Positivity \% in Swab & 24 & 7 & 29.2 \\
$\begin{array}{l}\text { Positivity \% in Disposal } \\
\text { Positivity \% in Water }\end{array}$ & 24 & 8 & 33.3 \\
$\begin{array}{l}\text { Positivity \% in Total } \\
\text { environmental sample }\end{array}$ & 72 & 0 & 0 \\
\hline
\end{tabular}

H9N2 positivity in the environmental samples was very much similar with those of tissue samples. Pearson's correlation coefficient (r) between the positivity of tissue and environmental samples was found to be 0.92 which indicates a strong correlation between environmental positivity and the positivity of tissue samples (Fig. 2).

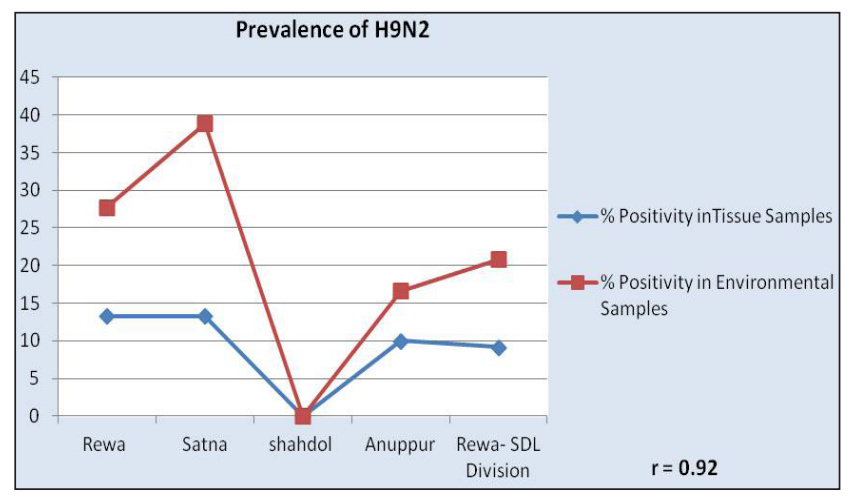

Fig. 2: Correlation between Positivity of H9N2 in Tissue samples and Environmental Samples

Persistence of virus in the environment is dependent on many physical factors including the temperature and relative humidity as well as the nature of surface on which the virus is present and other factors like presence of organic matter, cleaning and disinfection frequency etc (Kurmi et al., 2013). H9N2 virus is ubiquitously isolated from air and environmental swabs from live poultry markets Zhou et al. (2017). Presence of H9N2 virus in wastes and the absence of proper protocol for its disposal might pose a risk to stray animals and people handling such waste to contract the virus (Sun et al., 2013). It emphasizes the necessity of proper disposal of RPS wastes. Isolation of the viruses from environmental samples indicated the risk of these shops acting as a source of infections to others. Most of the shops were open on all days of week which may be contributing to the maintenance of continuity of virus in subsequent lots of poultry. Control measures aiming at the remission of viral loads and break in the viral persistence in RPSs such as sanitation and hygiene, "all in all out" system of poultry movement, discard of residual feed, are crucial.

The poultry birds which were found positive for H9N2 might have acquired the infection from any of the step from procuring sources to the PRSs. Considering the threat of H9N2 in poultry is present in eastern Madhya Pradesh it is recommended that a detail study should be conducted to find out the status of H9N2 virus all over the Madhya Pradesh and identify the potential risk factors involve in transmission and maintenance of infection. The findings of our study warrant a need to develop comprehensive awareness programme for all the stakeholderrs regarding the biosafety and biosecurity measures that are required to be followed at all the levels of procurement, transport, retail and sale of the poultry.

\section{ACKNOWLEDGEMENTS}

Authors are thankful to ICAR for providing funds to carry out this research work under Outreach of Zoonosis Project. Thanks, are also due to Director, ICAR-NIHSAD for extending the necessary facilities to carry out this work

\section{REFERENCES}

Alexander, D.J. 2000. A review of avian influenza in different bird species. Vet. Microbiol., 74(1-2): 3-13.

Ali, M., Yaqub, T., Mukhtar, N., Imran, M., Ghafoor, A., Shahid, M.F., Yaqub, S., Smith, G.J., Su, Y.C. and Naeem, M. 2018. Prevalence and phylogenetics of H9N2 in backyard and commercial poultry in Pakistan. Avian Dis., 62(4): 416-424.

Chaudhry, M., Rashid, H.B., Angot, A., Thrusfield, M., Barend, M., Capua, I., Cattoli, G., Welburn, S.C. and Eisler, M.C. 
2018. Risk factors for avian influenza H9 infection of chickens in live bird retail stalls of Lahore district, Pakistan 2009-2010. Sci. Rep., 8(1): 1-8.

Chu, D.H., Okamatsu, M., Matsuno, K., Hiono, T., Ogasawara, K., Nguyen, L.T., Van Nguyen, L., Nguyen, T.N., Nguyen, T.T., Van Pham, D. and Nguyen, D.H. 2016. Genetic and antigenic characterization of H5, H6 and $\mathrm{H} 9$ avian influenza viruses circulating in live bird markets with intervention in the center part of Vietnam. Vet. Microbiol., 192: 194-203.

Gomaa, M.R., Kayed, A.S., Elabd, M.A., Zeid, D.A., Zaki, S.A., El Rifay, A.S., Sherif, L.S., McKenzie, P.P., Webster, R.G., Webby, R.J. and Ali, M.A. 2015. Avian influenza A (H5N1) and A (H9N2) seroprevalence and risk factors for infection among Egyptians: a prospective, controlled seroepidemiological study. J. Infect. Dis., 211(9): 1399-1407.

Guan, Y., Shortridge, K.F., Krauss, S. and Webster, R.G., 1999. Molecular characterization of H9N2 influenza viruses: were they the donors of the "internal" genes of H5N1 viruses in Hong Kong?. Proc. Natl. Acad. Sci., 96(16): 9363-9367.

Kausar, A., Anwar, S., Siddique, N., Ahmed, S. and Dasti, J.I. 2018. Prevalence of avian influenza H9N2 virus among wild and domesticated bird species across Pakistan. Pak. J. Zool., 50(4): 1347-1354.

Khan, S.U., Anderson, B.D., Heil, G.L., Liang, S. and Gray, G.C. 2015. A systematic review and meta-analysis of the seroprevalence of influenza A (H9N2) infection among humans. J. Infect. Dis., 212(4): 562-569.

Kurmi, B., Murugkar, H.V., Nagarajan, S., Tosh, C., Dubey, S.C. and Kumar, M. 2013. Survivability of highly pathogenic avian influenza $\mathrm{H} 5 \mathrm{~N} 1$ virus in poultry faeces at different temperatures. Indian. J. Virol., 24(2): 272-277.

Lam, T.T., Wang, J., Shen, Y., Zhou, B., Duan, L., Cheung, C.L., Ma, C., Lycett, S.J., Leung, C.Y., Chen, X., Li, L., Hong, W., Chai, Y., Zhou, L., Liang, H., Ou, Z., Liu. Y., Farooqui, A., Kelvin, D.J., Poon, L.L., Smith, D.K., Pybus, O.G., Leung, G.M., Shu, Y., Webster, R.G., Webby, R.J., Peiris, J.S., Rambaut, A., Zhu, H. and Guan, Y. 2013. The genesis and source of the H7N9 influenza viruses causing human infections in China. Nature, 502(7470): 241-244.

Lee, H.J., Kwon, J.S., Lee, D.H., Lee, Y.N., Youn, H.N., Lee, Y.J., Kim, M.C., Jeong, O.M., Kang, H.M., Kwon, J.H. and Lee, J.B. 2010. Continuing evolution and interspecies transmission of influenza viruses in live bird markets in Korea. Avian Dis., 54(s1): 738-748.

Lee, M.S., Chang, P.C., Shien, J.H., Cheng, M.C. and Shieh, H.K. 2001. Identification and sub-typing of avian influenza viruses by reverse transcription-PCR. J. Virol. Methods., 97(1-2): 1322.
Li, S., Zhou, Y., Song, W., Pang, Q. and Miao, Z. 2016. Avian influenza virus H9N2 seroprevalence and risk factors for infection in occupational poultry-exposed workers in Tai'an of China. J. Virol. Methods, 88(8): 1453-1456.

Liu, R., Zhao, B., Li, Y., Zhang, X., Chen, S. and Chen, T. 2018. Clinical and epidemiological characteristics of a young child infected with avian influenza A (H9N2) virus in China. $J$. Int. Med. Res., 46(8): 3462-3467.

Office International des Epizooties (OIE). 2015. Manual of diagnostic tests and vaccines for terrestrial animals. Avian Influenza, Chapter 2.3.4. (NB: Version adopted in May 2015). https://www.oie.int/fileadmin/Home/eng/Health_standards/ tahm/3.03.04 AI.pdf

Office International des Epizooties (OIE). 2020. Immediate Notification of Highly pathogenic influenza A viruses (H5N1) (Infection with) (non-poultry including wild birds),India. Accessed on 05 September 2020. <https://www.oie.int/ wahis_2/public/wahid.php/Reviewreport/Review?page_refe $\mathrm{r}=$ MapFullEventReport\&reportid=34517>

Pawar, S.D., Tandale, B.V., Raut, C.G., Parkhi, S.S., Barde, T.D., Gurav, Y.K., Kode, S.S. and Mishra, A.C. 2012. Avian influenza H9N2 seroprevalence among poultry workers in Pune, India, 2010. PLoS. One., 7(5): e36374.

Peacock T.P., James. J., Sealy, J.E. and Iqbal, M.A. 2019. Global Perspective on H9N2 Avian Influenza Virus. Viruses, 9(11): 620.

Shen, Y.Y., Ke, C.W., Li, Q., Yuan, R.Y., Xiang, D., Jia, W.X., Yu, Y.D., Liu, L., Huang, C., Qi, W.B. and Sikkema, R. 2016. Novel reassortant avian influenza A (H5N6) viruses in humans, Guangdong, China, 2015. Emerg. Infect. Dis., 22(8): 1507.

Sun, X., Xu, X., Liu, Q., Liang, D., Li, C., He, Q., Jiang, J., Cui, Y., Li, J., Zheng, L. and Guo, J. 2013. Evidence of avian-like H9N2 influenza A virus among dogs in Guangxi, China. Infect. Genet. Evol., 20: 471-475.

Suarez, D.L., Senne, D.A., Banks, J., Brown, I.H., Essen, S.C., Lee, C.W., Manvell, R.J., Mathieu-Benson, C., Moreno, V., Pedersen, J.C. and Panigrahy, B., 2004. Recombination resulting in virulence shift in avian influenza outbreak, Chile. Emerg. Infect. Dis., 10(4): 693.

Thuy, D.M., Peacock, T.P., Bich, V.T.N., Fabrizio, T., Hoang, D.N., Tho, N.D., Diep, N.T., Nguyen, M., Trang, H.T.T., Choisy, M. and Inui, K., 2016. Prevalence and diversity of H9N2 avian influenza in chickens of Northern Vietnam, 2014. Infect, Genet. Evol., 44: 530-540.

Tong, S., Zhu, X., Li, Y., Shi, M., Zhang, J., Bourgeois, M., Yang, H., Chen, X., Recuenco, S., Gomez, J. and Chen, L.M. 2013. New world bats harbor diverse influenza A viruses. PLoSpathog, 9(10): 1003657. 
Turner, J.C., Feeroz, M.M., Hasan, M.K., Akhtar, S., Walker, D., Seiler, P., Barman, S., Franks, J., Jones-Engel, L., McKenzie, P. and Krauss, S. 2017. Insight into live bird markets of Bangladesh: an overview of the dynamics of transmission of $\mathrm{H} 5 \mathrm{~N} 1$ and H9N2 avian influenza viruses. Emerg. Microbes Infect., 6(1): 1-8.
Zhou, J., Wu, J., Zeng, X., Huang, G., Zou, L., Song, Y., Gopinath, D., Zhang, X., Kang, M., Lin, J. and Cowling, B.J. 2016. Isolation of H5N6, H7N9 and H9N2 avian influenza A viruses from air sampled at live poultry markets in China, 2014 and 2015. Euro. Surveill., 21(35): 30331. 
